\title{
HOW DO LEISURE CONSTRAINTS INFLUENCE THE REVISIT INTENTIONS OF MUSIC FESTIVAL VISITORS?
}

\author{
MAIKEL NUIJTEN, PIETER DE ROOIJ, AND LAURENT SNOECKX \\ NHTV Breda University of Applied Sciences, Breda, The Netherlands
}

\begin{abstract}
Leisure constraints affecting participation can be divided into intrapersonal, interpersonal, and structural constraints. Only a few studies in the event industry have investigated the role of leisure constraints. These studies show different effects of leisure constraints on participation. The purpose of this article is to examine the influence of leisure constraints on revisit intention regarding music festivals. This study is of quantitative nature and utilizes survey research. A sample of 1,063 respondents was used within the analyses, measuring the influence of perceived constraints on revisit intention. The results show that intrapersonal constraints (a lack of importance and interest) and structural constraints (travel time, a lack of time, costs, and a lack of satisfaction with the festival area) significantly influence revisit intention. In line with results from other leisure industries, intrapersonal constraints show the strongest effects. Interpersonal constraints do not affect revisit intentions. Music festivals should ideally maintain a high level of engagement with the visitors throughout the year to ensure continuous involvement.
\end{abstract}

\section{Key words: Leisure constraints; Revisit intention; Music; Events; Festivals}

\section{Introduction}

Over the past few decades many studies have investigated leisure constraints in diverse contexts. The leisure constraints theory is the most widely adopted model to explain differential leisure participation. Constraints are mostly divided into intrapersonal, interpersonal, and structural constraints (Crawford \& Godbey, 1987). The investigated leisure areas include park usage (Mowen, Payne, \& Scott, 2005; Zanon, Doucouliagos, Hall,
\& Lockstone-Binney, 2013), sports (Alexandris, Funk, \& Pritchard, 2011; Casper, Bocarro, Kanters, \& Floyd, 2011), and tourism (Gilbert \& Hudson, 2000; Hudson \& Gilbert, 2000; Hung \& Petrick, 2010). Only a few studies have focused on the events industry, and even fewer have considered music festivals. Boo, Carruthers, and Busser (2014) investigated constraints and negotiation strategies by nonparticipants of a community festival. Their study showed that structural constraints were most powerful in preventing people attending

Address correspondence to Maikel Nuijten, NHTV Breda University of Applied Sciences, Breda, The Netherlands.

E-mail: maikel.nuijten@gmail.com 
the festival. Funk, Alexandris, and Ping (2009) investigated constraints of attending an international sports event. Their study showed that the intrapersonal constraints were the most powerful. Santos-Lewis and Moital (2013) applied a qualitative approach into the relationship between constraints for salsa dancing and attending salsa events and level of specialization. They identified intrapersonal, interpersonal, and structural constraints in all levels of specialization. Overall, the inconsistent results from previous studies indicate that leisure constraints embody a different role for each kind of context or setting. This study seeks to clarify how leisure constraints relate to the specific context of a music festival and by doing so provide accurate implications for a specific music festival setting.

The research context of this study is a 4-day international music festival, located at a popular music venue in the Netherlands. Empirical research was conducted on the constraints that visitors might experience to visit the festival again. In other words, the study aims to provide solutions on how to retain visitors within a music festival context. Overall, this study investigated the link between leisure constraints and revisit intention. Revisit intention can be described as the degree to which visitors are planning to visit again (Huang, 2009; Quintal \& Polczynski, 2010; Shen, 2014).

The following research question was used as pillar of the present study: How are specific constraints related to the intention to revisit a music festival the following year?

\section{Leisure Constraints}

Leisure constraints are "internal (intrapersonal) psychological states, attributes, and characteristics, and external (interpersonal and situational) circumstances which are experienced as individual behavioral restraining forces" (Crawford \& Godbey, 1987, p. 122). In other words, leisure constraints are perceived or experienced barriers or prohibitive factors affecting the formation of leisure preferences and inhibiting continued leisure behavior (Casper et al., 2011; Hawkins, Peng, Hsieh, \& Eklund, 1999; Hung \& Petrick, 2010). Constraints do not necessarily lead to nonparticipation, but may also affect participation levels
(Nadirova \& Jackson, 2000; Zanon et al., 2013). Based on the seminal study of Crawford and Godbey (1987), many researchers divide constraints into three categories. First, intrapersonal constraints are individual, psychological states or characteristics inhibiting leisure preferences and behavior. These constraints include beliefs or attitudes about leisure activities and perceived skills required to perform these activities (Casper et al., 2011; Palen et al., 2010). Second, interpersonal constraints are social factors, associated with interactions between individuals and relationships. Examples are family responsibilities or a lack of friends having the same interests. Third, structural constraints are barriers raised by organizations, external to an individual and his social world (Casper et al., 2011). These factors include costs, facilities, proximity, transportation, the time at which an individual should consume a leisure activity, or in general term "availability of opportunity” (Hawkins et al., 1999; Palen et al., 2010; Zanon et al., 2013). Crawford, Jackson, and Godbey (1991) presented a hierarchical model linking the three constraints in a hierarchical way. They assumed that individuals experience the constraints in a sequential order. Intrapersonal constraints are the first and most important barriers to impact preferences, followed by interpersonal constraints. Finally, structural constraints influence leisure participation after preferences have been constructed. Other researchers do not assume that the constraints are hierarchical in order, but they stress the dynamic and cumulative effects of constraints (Hawkins et al., 1999; Henderson, 1997). They argue that constraints are not supposed to be isolated, but that they are interrelated (Gilbert \& Hudson, 2000). Moreover, the importance of the constraints depends on the level of participation (Nadirova \& Jackson, 2000). These levels vary from nonparticipation, participation, and ceasing participation (Gilbert \& Hudson, 2000).

The nature of various leisure activities differ to a great extent. This implies that the constraints will likely show great variety (Godbey, Crawford, \& Shen, 2010). A study by McCarville and Smale (1993) of constraints to five leisure activity domains (physical activities, arts, hobbies, social activities, and home-based entertainment) 
showed that perceived constraints vary across these domains. The nature of the leisure activity domain influenced whether interpersonal, intrapersonal, or structural constraints had effects on participation. Therefore, many researchers adopted an activity- or domain-specific approach in their studies (Gilbert \& Hudson, 2000; Hawkins et al., 1999). This study followed this approach and, given the study object (a music festival), a review of the main constraints attending events and performing arts is presented here.

\section{Constraints to Attending a Music Festival}

Based on the research contexts of leisure events and performing arts seven constraints were identified (Fig. 1). These constraints were categorized under structural (travel time, costs, time, and festival area), interpersonal (social relationships), and intrapersonal (artists and involvement) constraints (Boo et al., 2014; Hung \& Petrick, 2010;
Kay, Wong, \& Polonsky, 2009; Pritchard, Funk, \& Alexandris, 2009).

\section{Structural Constraints}

Travel Time. The impact of travel time on revisit intention regarding music festivals has not been studied extensively. Research within the performing arts context shows that travel time is an antecedent for customer loyalty (Currim, Weinberg, \& Wittink, 1981). Living near a theater could increase visitation and displaying loyal behavior (Van den Broek, 2008; Verhoeff \& Ganzeboom, 1991). Furthermore, it was identified that travel time positively influenced money spent at a festival (Thrane, 2002a). However, the effect of travel time on revisit intention within the music festival context does not exist in the reviewed literature.

H1: Travel time has a negative impact on revisit intention.

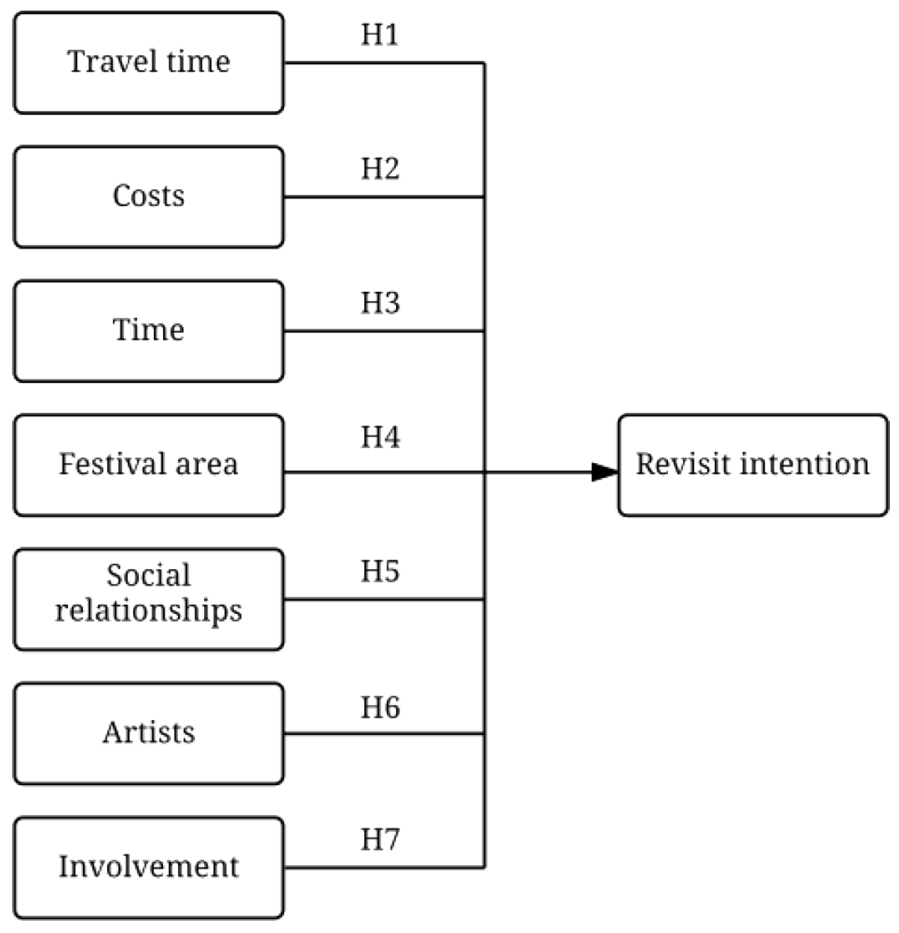

Figure 1. Conceptual model of constraints influencing revisit intention. 
Costs. The relevance of costs is heavily discussed in the literature. Some studies point out that the price of performing arts events plays an important role in the decision-making process. Prices are cited as a (main) reason not to attend performing arts events (Andreasen, 1991; Colbert, Beauregard, \& Vallée, 1998, Meijjer, Warntjes, \& Van de Velde, 2007), and they are an important subscription attribute (Currim et al., 1981). According to Schimmelpfennig (1997), performing arts tickets are price-elastic. Other studies point out, however, that prices are not really a barrier. Following Scheff Bernstein (2006) most nonattenders would not attend, even if the tickets were half price. A study of Reddy, Swaminathan, and Motley (1998) showed that ticket prices do not have a significant relationship with attendance of Broadway shows. According to Felton (1992), performing arts tickets are price-inelastic. In conclusion, it is argued that prices might play a role in attending music festivals because prices can have an effect on purchases of especially low-income groups (Colbert et al., 1998). Therefore, it was hypothesized that:

\section{H2: Costs have a negative impact on revisit intention.}

Time. Time can be described as having the opportunity to go somewhere (Crawford \& Godbey, 1987). Crawford and Godbey (1987) describe time as an opportunity one needs to have in order to participate. It is rather difficult to influence this opportunity as people might place things other than visiting a festival as more important (Santos-Lewis \& Moital, 2013). The availability of time is heavily discussed as a relevant factor within the performing arts (De Rooij, 2013). A lack of time is one of the main reasons for attending, attending less often, or becoming a regular visitor. However, a lack of time can also be interpreted as an excuse to cover up limited interests (De Rooij, 2013). When people are seriously interested, they are likely to create time to participate and restructure their priorities. Therefore, to indicate time, it is relevant to assess an individual's priorities. This could entail family issues, visiting another event, or spending money differently (Borland \& MacDonald, 2003; Hung \& Petrick, 2010). In this study, timing is characterized by three types of commitment or having other priorities such as family, work/study, and social commitments.

H3: A lack of time has a negative impact on revisit intention.

Festival Area. The festival area can be referred to as the secondary product of a performing arts activity and entails the atmosphere, facilities, and personnel (De Rooij, 2013). A study regarding event visitors' satisfaction and loyalty towards the event performance emphasized the importance of the festival area (Özdemır \& Çulha, 2009). They merged variables and constructed festival area with items such as "satisfaction with the facilities" and "the atmosphere.” Apart from festival area, festival quality can be seen as all indicators that contribute to the visitor's perception of the festival (Saleh \& Ryan, 1993). Similar to the constraint "artists," the perception of the festival area is personal and therefore considered as an intrapersonal constraint. According to Saleh and Ryan (1993), the perception of festival quality entails indicators similar to the festival area. A lack of satisfaction with both the facilities and the atmosphere could be constraints not to visit a festival (Schofield \& Thompson, 2007).

H4: A lack of satisfaction with the festival area has a negative impact on revisit intention.

\section{Interpersonal Constraint}

Social Relationships. Many studies emphasize the importance of the social character for visitors in deciding whether to revisit a festival (Caldwell, 2001; Nicholson \& Pearce, 2001). Socialization entails all factors that might influence the social interaction before, during, and after a performing arts experience (Caldwell, 2001). When focusing on constraints to visit, consumers are particularly interested in the influence others have before visiting a music festival (Oliver, 1999). Different from Caldwell (2001) and Oliver (1999), who merely studied aspects of socialization, Pritchard et al. (2009) studied social constraints influencing repeat visit behavior. In their study "social relationships" was regarded as a lack of family or friends interested to jointly attend a music festival. 
H5: A lack of social relationships has a negative impact on revisit intention.

\section{Intrapersonal Constraints}

Artists. The artists deliver the experience and determine the overall satisfaction of the festival visitors (Garbarino \& Johnson, 2001). The performance is considered to be the main reason for attendance and can be described as the primary product of a performing arts activity (De Rooij, 2013). Following Boerner, Moser, and Jobst (2011), one of the main services within a performing arts event is the principal performer. In order to assess the performers, the degree of liking the artists should be measured (Boerner \& Jobst, 2013). As the degree of liking these principal performers is a personal perception, "artists" is considered an intrapersonal constraint. A study towards the motivations and preferred experiences of music festival visitors emphasizes the importance of competitive comparisons, especially between principal performers (Pegg \& Patterson, 2010). In this matter, the satisfaction of visitors with the possible differences between the research subject and any competitive music fesitvals was also considered in this study.

H6: A lack of satisfaction with the artists has a negative impact on revisit intention.

Involvement. Among the predictors of attending performing arts, people's interests are strongly emphasized (Andreasen \& Belk, 1980; Kay et al., 2009). As having a certain interest can be seen as a part of involvement (Decloe, Kaczynski, \& Havitz, 2009), involvement was studied rather than merely one's interest. Involvement can be considered long term (enduring) or short term (situational) (Decloe et al., 2009; Havitz \& Mannell, 2005). In this study involvement was defined as being attracted to an event that determines the degree of interest towards that event (Lee \& Beeler, 2009; Zaichkowsky, 1985). It was hypothesized that a lack of involvement has a negative impact on revisit intention.

H7: A lack of involvement has a negative impact on revisit intention.

\section{Methodology}

This section presents the process of collecting data as well as the instrument used in this study.

\section{Data Collection}

Empirical research was conducted within one of the largest popular music venues in the Netherlands. The subject of the present study is the 4-day international music festival called "Roadburn." This festival is one of Europe's leading underground festivals for psychedelic, avant-garde, doom, or any other variation of left-field sonic music. Roadburn is organized by popular music venue 013 and possesses all e-mail addresses of all ticket buyers within the past 7 years. Online software Parantion Web Survey ${ }^{\circledR}$ was used to create an online survey. On behalf of the founders of the music festival, this survey was attached to an e-mail received by former visitors of the festival. A total of 5,205 e-mails were sent, leading to a response rate of $20.4 \%$ with a bounce rate of $0.2 \%$, indicating that eight surveys did not arrive. This led to a satisfying response of 1,063 individuals that completely filled out the online survey, consisting of 928 (87\%) men and 135 (13\%) women. The average age was 33 years old. Visitors from 42 different countries and all six continents were present, confirming the international character of the festival. Table 1 shows the demographics including gender, the division of age groups, and the top five represented countries at Roadburn. The data set could easily be exported into SPSS, the statistical program used to analyze the collected data.

\section{Instrument}

As this study is focused on intentions to revisit, the entire research population (i.e., all visitors) was deemed suitable to participate in the online survey. Based on an extensive literature review, 27 survey items were selected to be part of this study (see Table 2). First, the scale for "travel time” was created by the author as no accurate scale was found in the literature. Due to the international character of the festival, travel times are between approximately $15 \mathrm{~min}$ and $10 \mathrm{hr}$ or more. Second, the foundation of the scale for "costs" 
Table 1

Demografic Information $(N=1,063)$

\begin{tabular}{lc}
\hline & Number (\%) \\
\hline Gender & \\
$\quad$ Male & $928(87.3 \%)$ \\
Female & $135(12.7 \%)$ \\
Age & \\
20-30 years old & $271(25.5 \%)$ \\
$31-40$ years old & $498(46.8 \%)$ \\
41-50 years old & $244(23.0 \%)$ \\
51-60 years old & $42(4.0 \%)$ \\
61-70 years old & $7(0.7 \%)$ \\
Country & \\
Netherlands & $268(25.4 \%)$ \\
Germany & $135(12.7 \%)$ \\
UK & $110(10.5 \%)$ \\
Belgium & $77(7.2 \%)$ \\
Sweden & $68(6.4 \%)$ \\
\hline
\end{tabular}

Note. Percentages and number may not add up due to decimal errors or missing values. Only the top five countries of residents are displayed.

was derived from Nyaupane, Morais, and Graefe (2004). Third, the items for "social relationships" were based on a study by Boo et al. (2014). Fourth, the constraint "time" has found its origin in a study towards leisure constraints based on sport participation levels by Alexandris and Carroll (1997). Fifth, Garbarino and Johnson (2001) provided a scale for this study to be able to measure the impact of "artists" on revisit intention. Sixth, three items were derived from De Rooij (2013) to construct the constraint "festival area." Seventh, "involvement" was extensively measured and constructed within 10 items by Lee and Beeler (2009). Some items were modified to improve accuracy, reliability, and relevance. Together these items form seven constraints that were tested for their impact on revisit intention.

All items (except "travel time") were scored on a 5-point Likert scale, ranging from $1=$ strongly disagree to $5=$ strongly agree. The dependent variable "revisit intention" was included through an indication of the intention to visit again next year, also on a 5-point Likert scale ranging from $1=$ very unlikely to $5=$ very likely (Thrane, 2002b). The items used in this study, along with reliability coefficients, can be found in Table 2 . The next section entails the results of principal components analysis, descriptive statistics, and multiple regression analyses.

\section{Findings}

Subsequently, a factor analysis, descriptive statistics, and a multiple regression analysis were conducted and analyzed.

\section{Factor Analysis}

A principal component analysis (PCA) was conducted on 26 items with orthogonal rotation (varimax). The Kaiser-Meyer-Olkin measure verified the sampling adequacy for the analysis, $\mathrm{KMO}=0.85$, and all $\mathrm{KMO}$ values for each item were $>0.68$, which is above the acceptable 0.50 value (Field, 2009). Bartlett's test of sphericity indicated that correlations between items were sufficiently large for PCA, $\chi^{2}(325)=10862.87$, $p<0.001$. An initial analysis was run to obtain eigenvalues for each component in the data. Seven components had eigenvalues over Kaiser's criterion of 1 and explained together $64.83 \%$ of the variance. As the sample size was greater than 250 (1,064), and the average communality was 0.65 , Kaiser's criterion is accurate (Field, 2009). Moreover, Table 2 shows that all factors had high reliabilities because all Cronbach's alpha values exceeded 0.7.

The factor analysis did not include the factor "travel time" as it only consists of one item indicating the duration of travel time of each visitor. The initial factor "involvement" was split into two separate factors by the PCA, which is most likely due to the four reverse-scored items within "involvement." Various analyses such as Maximum Likelihood Factor Analysis were conducted to avoid this division; however, no improvements were observed. In addition, recoding the data set to align all items in a similar direction did not improve the results. Hence, further analyses have considered "involvement" as "interest" and "importance," respectively, making Hypothesis 7 twofold and therefore altering the hypothesis set up. Hypothesis 7a reads that a lack of importance negatively influences the revisit intention. Hypothesis $7 \mathrm{~b}$ reads that interest positively (due to reverse scored items) influences the revisit intention. Apart from "involvement," the 
Table 2

Summary of the Factor Analysis Results $(N=1,063)$

\begin{tabular}{|c|c|c|c|c|c|c|c|}
\hline \multirow[b]{2}{*}{ Item } & \multicolumn{7}{|c|}{ Rotated Factor Loadings } \\
\hline & Importance & Interest & $\begin{array}{c}\text { Social } \\
\text { Relationships }\end{array}$ & $\begin{array}{c}\text { Festival } \\
\text { Area }\end{array}$ & Timing & Artists & Costs \\
\hline Means a lot to me/Means nothing to me & 0.845 & & & & & & \\
\hline Important/Unimportant & 0.833 & & & & & & \\
\hline Matters to me/Does not matter & 0.823 & & & & & & \\
\hline Valuable/Worthless & 0.750 & & & & & & \\
\hline Essential/Nonessential & 0.717 & & & & & & \\
\hline Beneficial/Not beneficial & 0.711 & & & & & & \\
\hline Boring/Interesting & & 0.852 & & & & & \\
\hline Unexciting/Exciting & & 0.811 & & & & & \\
\hline Uninterested/Interested & & 0.801 & & & & & \\
\hline Useless/Useful & & 0.498 & & & & & \\
\hline $\begin{array}{l}\text { I don’t have friends or acquaintances with } \\
\text { whom to participate }\end{array}$ & & & 0.808 & & & & \\
\hline $\begin{array}{l}\text { People with whom I would participate have no } \\
\text { interest in the event }\end{array}$ & & & 0.759 & & & & \\
\hline $\begin{array}{l}\text { People with whom I would participate live too } \\
\text { far away }\end{array}$ & & & 0.723 & & & & \\
\hline $\begin{array}{l}\text { People with whom I would participate are on } \\
\text { different work schedules }\end{array}$ & & & 0.708 & & & & \\
\hline I am satisfied with the personnel at Roadburn & & & & 0.794 & & & \\
\hline I am satisfied with the atmosphere at Roadburn & & & & 0.766 & & & \\
\hline I am satisfied with the facilities at Roadburn & & & & 0.756 & & & \\
\hline $\begin{array}{l}\text { Social commitments prevent me from partici- } \\
\text { pating in Roadburn }\end{array}$ & & & & & 0.820 & & \\
\hline $\begin{array}{l}\text { Family prevents me from participating in } \\
\text { Roadburn }\end{array}$ & & & & & 0.772 & & \\
\hline $\begin{array}{l}\text { Work/studies prevents me from participating } \\
\text { in Roadburn }\end{array}$ & & & & & 0.731 & & \\
\hline $\begin{array}{l}\text { Satisfaction with the artists' performances is } \\
\text { important }\end{array}$ & & & & & & 0.767 & \\
\hline $\begin{array}{l}\text { Quality of artists compared to other music } \\
\text { festivals is important }\end{array}$ & & & & & & 0.765 & \\
\hline Artists are highly skilled & & & & & & 0.741 & \\
\hline Roadburn in general is expensive & & & & & & & 0.820 \\
\hline The ticket price for Roadburn is expensive & & & & & & & 0.805 \\
\hline The Roadburn camping is expensive & & & & & & & 0.702 \\
\hline Eigenvalues & 4.047 & 2.565 & 2.379 & 2.053 & 1.974 & 1.948 & 1.889 \\
\hline$\%$ of variance & 15.567 & 9.866 & 9.150 & 7.896 & 7.594 & 7.493 & 7.266 \\
\hline$\alpha$ & 0.894 & 0.782 & 0.766 & 0.759 & 0.715 & 0.705 & 0.701 \\
\hline
\end{tabular}

PCA groups the constraints/scales exactly as set up and thus recognizes and supports the prespecified Hypotheses 2 to 6 . This means that all constraints can be confidently used within subsequent analyses to test the hypotheses.

\section{Descriptive Statistics}

Table 3 shows that the visitors are likely to return next year as the mean of all visitors was considered slightly above "likely" on the scale whether to visit next year $($ mean $=4.11)$.

\section{Which Constraints Influence the Revisit Intention of Festival Visitors?}

Factor analysis revealed seven factors. In addition, "travel time" was taken into account by means of a dummy variable. This section entails a multiple regression analysis that tested these eight 
Table 3

Means and Standard Deviations per Item and Variable

\begin{tabular}{|c|c|c|}
\hline Construct & Mean & $S D$ \\
\hline $\begin{array}{l}\text { Travel time } \\
\quad 0-29 \text { min (10\%); 30-59 min (12\%); 1-5 hr (40\%); 6-10 hr (23\%); >10 hr (15\%) }\end{array}$ & 3.23 & \\
\hline Costs (reverse scored) ${ }^{\mathrm{a}}$ & 3.08 & \\
\hline The ticket price for Roadburn is expensive & 3.08 & 1.017 \\
\hline The Roadburn camping is expensive & 3.01 & 0.792 \\
\hline Roadburn in general is expensive & 3.14 & 1.005 \\
\hline Artists $^{\mathrm{a}}$ & 4.53 & \\
\hline Satisfaction with the artists' performances is important & 4.63 & 0.590 \\
\hline Artists are highly skilled & 4.43 & 0.696 \\
\hline Quality of artists compared to other music festivals is important & 4.53 & 0.708 \\
\hline Festival area $^{\mathrm{a}}$ & 4.56 & \\
\hline I am satisfied with the facilities at Roadburn & 4.37 & 0.716 \\
\hline I am satisfied with the atmosphere at Roadburn & 4.75 & 0.556 \\
\hline I am satisfied with the personnel at Roadburn & 4.57 & 0.641 \\
\hline Social relationships (reverse scored) ${ }^{\mathrm{a}}$ & 2.17 & \\
\hline I don't have friends or acquaintances with whom to participate & 1.89 & 1.072 \\
\hline People with whom I would participate are on different work schedules & 2.39 & 1.051 \\
\hline People with whom I would participate live too far away & 2.23 & 1.102 \\
\hline People with whom I would participate have no interest in the event & 2.15 & 1.124 \\
\hline Time (reverse scored) ${ }^{\mathrm{a}}$ & 1.74 & \\
\hline Family prevents me from going to Roadburn & 1.55 & 0.885 \\
\hline Work/studies prevents me from going to Roadburn & 2.03 & 1.134 \\
\hline Social commitments prevent me from going to Roadburn & 1.63 & 0.845 \\
\hline Importance (reverse scored) & 1.83 & \\
\hline Roadburn is important/unimportant to me & 1.84 & 0.895 \\
\hline Roadburn means a lot/nothing to me & 1.79 & 0.871 \\
\hline Roadburn is valuable/valueless to me & 1.68 & 0.846 \\
\hline Roadburn is beneficial/nonbeneficial to me & 1.98 & 0.921 \\
\hline Roadburn is essential/nonessential to me & 1.99 & 0.956 \\
\hline Roadburn matters/doesn't matter to me & 1.70 & 0.833 \\
\hline Interest & 4.31 & \\
\hline Roadburn is boring/interesting to me & 4.54 & 0.818 \\
\hline Roadburn is unexciting/exciting to me & 4.49 & 0.812 \\
\hline Roadburn is uninterested/interested to me & 4.41 & 0.921 \\
\hline Roadburn is useless/useful to me & 3.81 & 1.130 \\
\hline Revisit intention & 4.11 & \\
\hline
\end{tabular}

(1) strongly disagree to (5) strongly agree.

variables for its influence on the revisit intention of festival visitors (Table 4).

Pearson's correlation revealed that the factors “festival area," "time," "importance," and "interest" have a medium effect size $(r= \pm 0.3$, $p<0.001$ ), whereas "costs," "artists," "social relationships," and "travel time" have a small effect size ( $r= \pm 0.1, p<001)$, when correlated with revisit intention (Field, 2009). The predictors explained $20.4 \%$ of the variability in the outcome variable, $R^{2}=0.204$. The Durbin-Watson statistic (1.928) showed that the independent errors are satisfactory. The $95 \%$ confidence intervals for $B$ indicated that the overall model contains predictors that might vary across other samples. The VIF values and tolerance statistics indicated that there is hardly any collinearity within the data set. However, the variance proportions affirmed that the variables "artists" and "festival area," as well as "social relationships" and "time," are partly dependent. Finally, residual statistics of the extreme cases suggested that the overall model is fairly accurate, as $95.5 \%$ of the cases have standardized residuals. The multiple regression analysis brought to light that a lack of "importance" has the largest (negative) impact $(B=-0.358)$ on revisit intention, followed by satisfaction with the "festival area," which has a positive impact $(B=0.219)$ on revisit intention. 
Table 4

Summary of the Multiple Regression on Revisit Intention

\begin{tabular}{lcrrr}
\hline & $B$ & $S E B$ & $\beta$ & $p$ Value \\
\hline Constant & $3.168(2.254-4.082)$ & 0.466 & & 0.000 \\
Costs & $-0.122(-0.204-0.039)$ & 0.041 & -0.083 & 0.004 \\
Artists & $0.070(-0.057-0.197)$ & 0.065 & 0.034 & 0.277 \\
Festival area & $0.219(0.086-0.351)$ & 0.067 & 0.106 & 0.001 \\
Social relationships & $-0.050(-0.127-0.027)$ & 0.039 & -0.038 & 0.203 \\
Time & $-0.132(-0.217--0.047)$ & 0.043 & -0.093 & 0.002 \\
Importance & $-0.358(-0.457--0.260)$ & 0.050 & -0.237 & 0.000 \\
Interest & $0.138(0.041-0.235)$ & 0.049 & 0.092 & 0.005 \\
Travel time 0-29 min versus $>10 \mathrm{hr}$ & $0.402(0.158-0.646)$ & 0.124 & 0.109 & 0.001 \\
Travel time 30-59 min versus $>10 \mathrm{hr}$ & $0.531(0.299-0.763)$ & 0.118 & 0.157 & 0.000 \\
Travel time 1-5 hr versus $>10 \mathrm{hr}$ & $0.510(0.330-0.691)$ & 0.092 & 0.230 & 0.000 \\
Travel time 6-10 hr versus $>10 \mathrm{hr}$ & $0.385(0.190-0.580)$ & 0.099 & 0.149 & 0.000 \\
\hline
\end{tabular}

Note. The $B$ values also include the $95 \%$ lower and upper bound confidence intervals. When the base group "travel time $10 \mathrm{hr}$ ” changes into a comparison group such as "travel time 0-29 min," the dependent variable increases. Therefore, travel time has a negative influence on the dependent variable.

To summarize, it can be concluded that all predictors have a significant relationship with revisit intention, $p<0.001$. Nevertheless, "artists" and "social relationships" did not contribute significantly to the overall model. The constraints "costs," a lack of satisfaction with the "festival area," a lack of "time," a lack of "importance," a lack of "interest," and "travel time” significantly influence revisit intention, and these contraints seem representative for the population. The constraint mostly influencing the revisit intention of festival visitors was found to be a lack of "importance."

\section{Hypotheses Testing}

Answering the research question, 6 out of 8 constraints have a significant influence on revisit intention. Support was found for Hypotheses 1, 2, 4, 6, 7a and 7b (Table 5).

\section{Discussion}

Given the hypothesized and observed results of Table 4, each constraint will be discussed accordingly. First, travel time was suggested to have a negative impact on revisit intention (Currim et al.,

Summary of the Hypothesis Tests

\begin{tabular}{llc}
\hline & \multicolumn{2}{c}{ Revisit Intention } \\
\cline { 2 - 3 } & Hypothesized & Observed \\
\hline Structural & - & - \\
H1 Travel time & - & - \\
H2 Costs & - & - \\
H3 Lack of time & + & + \\
H4 Satisfaction with the festival area & - & 0 \\
Interpersonal & + & - \\
H5 Lack of social relationships & - & + \\
Intrapersonal & + & 0 \\
H6 Satisfaction with the artists & & \\
H7a Lack of importance & & \\
H7b Interest & & \\
\hline Note. + = significant positive effect; $-=$ significant negative effect; $0=$ no \\
effect. Based on PCA, the constraint interest was hypothesized as positive \\
due to reverse scored items. Satisfaction with the artists and festival area \\
were positively surveyed and thus retroactively hypothesized as positive.
\end{tabular}


1981). In line with the hypothesis a negative effect was observed. An increase in a person's travel time towards a music festival results in a decrease of that person's likelihood of revisiting a music festival. Second, as hypothesized, the costs of a music festival significantly influences the intention to revisit: Consumers' perceptions of costs negatively influence their future intentions. A reason for this might be that people express liking a music festival more because of interesting ticket prices (Baloglu, 2002). The results are in contrast with ideas of Scheff Bernstein (2006), who argues that ticket prices are not important for both considering and actually visiting performing arts events. However, it could be possible that the ticket price is less salient when people actually attend the performing arts in comparison to expressing intentions (Scheff Bernstein, 2006; Uncles, Dowling, \& Hammond, 2003). Third, it was hypothesized that a lack of social relationships had a negative effect on intentions. This study measured the availability of family and friends to attend a music festival. The results showed no effect of social relationships on future intentions. This might be explained by the specific character of the event (an underground music festival). Festival visitors might live in a specific social world with many friends having common music preferences. Fourth, the lack of time a visitor is willing to invest in a music festival is constraining revisit intention. In other words, social commitments towards work or family influence a person's intention to revisit.

Fifth, contradicting the hypothesized effect of artists, a lack of satisfaction with the artists had no impact on revisit intention. A reason for the latter effect can be found within the measurement scale used to indicate the constraint artists. The items of artists are closely related to importance, testing whether or not satisfaction with the artists is important. Sixth, the festival area is an important indicator to increase the intention to revisit a music festival. In line with these results, the literature suggests that the ambiance (i.e., atmosphere), facilities, and service (i.e., personnel) are important indicators of satisfaction, which ultimately leads to revisit intention (Wan \& Chan, 2013). Seventh, as hypothesized, a lack of importance has a negative and significant influence on the intention to revisit a music festival. In line with the results, it is suggested that when a music festival takes a central role and becomes an important aspect within an individual's life (Kyle, Absher, Hammitt, \& Cavin, 2006), it increases a person's revisit intention regarding this music festival. Lastly, supporting the hypothesis, interest has a positive effect on the intention to revisit.

As discussed previously, there are only a few quantitative studies investigating the role of constraints in the event industry showing different effects of leisure constraints. Boo et al. (2014) concluded that structural constraints are most relevant for attending a community festival. Funk et al. (2009) showed that intrapersonal constraints are most powerful in attending an Olympic sports event. Comparing our study with these two studies is difficult for three reasons. First, the studies have a different focus on stages of leisure pursuit. Boo et al. (2014) investigated nonparticipants, while in our study we focused on participants. Structural constraints appear to be most important for nonparticipants (Boo et al., 2014). We argue that for nonparticipants certain structural constraints (such as a lack of time) in fact reflect an excuse and that these constraints are a consequence of having a lack of interest (Zanon et al., 2013). Second, concepts have a different operationalization. Interpersonal constraints were measured with items related to "communism," "security," and "conditions with public facilities" in the study of Funk et al. (2009), while our items reflect social relationships. Third, the character of the event is different between the studies.

Crawford et al. (1991) presented a hierarchical model with a sequential order: intrapersonal constraints followed by interpersonal and structural constraints. Others emphasized the interrelatedness of these constraints (Gilbert \& Hudson, 2000; Hawkins et al., 1999). Godbey et al. (2010) stated that "actual constraints faced by a given individual do not have to start with intrapersonal constraints" (p. 117). Although Godbey et al. (2010) argued that there is no fixed sequential order and the strength and importance of constraints vary, they assumed intrapersonal constraints are most powerful. Our results are in line with this assumption.

\section{Implications}

Following the results of the present study, several managerial implications can be derived. First, in order to satisfy loyal visitors, music festivals 
should provide opportunities to overcome issues due to time constraints. Festivals could offer online communities, especially in case a festival attracts visitors from all over the globe. Potential visitors can share information, travel together, plan the trip ahead, and therefore overcome the constraint of social commitments. Second, music festivals are suggested to rely on a certain degree of involvement among their visitors. Therefore, festival managers should focus on customer touchpoints throughout the year to increase engagement and enhance the customer experience.

According to Zomerdijk and Voss (2010) these touchpoints are especially valuable before and after the experience. By creating an all-year-round digital platform where (revisiting) customers have the opportunity to connect with the music festival, the organization has the possibility to increase engagement before and after the event. Ultimately, these touchpoints should elicit a feeling of belonging to the music festival. Such a digital platform has no geographical constraints and can be executed quickly and inexpensively (Mahr, Lievens, \& Blazevic, 2014), which is particularly applicable to music festivals with worldwide visitors. Third, the present study shows that visitors consider pricing when intending to revisit a music festival. Festival managers should be aware that there is a limit to raising overall prices. They should consider increasing value for money and differentiate in two ways. On the one hand, offering both low-priced and luxurious ticket options for the same performance creates variety and makes the normal ticket price seem more favorable for visitors. On the other hand, music festivals could provide differentiated packages including extra (optional) benefits, such as private meetings with artists, transport to the customer's accommodation or a "behind-thescenes" tour.

\section{Future Research and Limitations}

The study is a case study with respondents from an international multiday music festival. Thus, the provided implications are limited to the context of the study. When considering other festival types and sizes, the impact of certain constraints on revisit intention might vary. Additionally, Lyu and Oh (2015) related leisure constraints to self-identity and social world identity. Given the specific character of the festival in our study (underground festival for psychedelic music), including theory and measures on identity formation might have provided additional valuable insights.

Future research should focus on the relationship between leisure constraints of intentional and actual behavior. Leisure constraints such as social relationships and costs potentially influence actual behavior differently from intentional behavior. In addition, including other indicators of the dependent variable besides visitation, such as the likelihood and actual engagement of word-of-mouth behavior, could reveal interesting implications. Possibly, leisure constraints that influence revisit intention might have a different impact on wordof-mouth behavior (Thrane, 2002b). As suggested previously, the impact of social relationships potentially becomes more salient within actual leisure behavior and could be analyzed more thoroughly. By doing so, it can be determined which aspects of these social relationships are more decisive than others, for which kind of revisit behavior. Last, the demographics confirmed the international and intercontinental character of the festival. Future research could focus on intercultural differences in perceiving barriers to revisit.

\section{References}

Alexandris, K., \& Carroll, B. (1997). An analysis of leisure constraints based on different recreational sport participation levels: Results from a study in Greece. Leisure Sciences, 19(1), 1-15.

Alexandris, K., Funk, D. C., \& Pritchard, M. (2011). The impact of constraints on motivation, activity attachment, and skier intentions to continue. Journal of Leisure Research, 43(1), 56.

Andreasen, A. (1991). Expanding the audience for the performing arts (National Endowment for the Arts, Report No. 24). Washington, DC: Seven Locks Press.

Andreasen, A. R., \& Belk, R. W. (1980). Predictors of attendance at the performing arts. Journal of Consumer Research, 7(2), 112.

Baloglu, S. (2002). Dimensions of customer loyalty: separating friends from well wishers. The Cornell Hotel and Restaurant Administration Quarterly, 43(1), 47-59.

Boerner, S., \& Jobst, J. (2013). Enjoying theater: The role of visitor's response to the performance. Psychology of Aesthetics, Creativity, and the Arts, 7(4), 391.

Boerner, S., Moser, V., \& Jobst, J. (2011). Evaluating cultural industries: Investigating visitors' satisfaction in theatres. The Service Industries Journal, 31(6), 877-895. 
Boo, S., Carruthers, C. P., \& Busser, J. A. (2014). The constraints experienced and negotiation strategies attempted by nonparticipants of a festival event. Journal of Travel \& Tourism Marketing, 31(2), 269-285.

Borland, J., \& MacDonald, R. (2003). Demand for sport. Oxford Review of Economic Policy, 19(4), 478-502.

Caldwell, M. (2001). Applying general living systems theory to learn consumers' sense making in attending performing arts. Psychology \& Marketing, 18(5), 497-511.

Casper, J. M., Bocarro, J. N., Kanters, M. A., \& Floyd, M. F. (2011). Measurement properties of constraints to sport participation: A psychometric examination with adolescents. Leisure Sciences, 33(2), 127-146.

Colbert, F., Beauregard, C., \& Vallée, L. (1998). The importance of ticket prices for theatre patrons. International Journal of Arts Management, 1(1), 8-15.

Crawford, D. W., \& Godbey, G. (1987). Reconceptualizing barriers to family leisure. Leisure Sciences, 9(2), 119-127.

Crawford, D. W., Jackson, E. L., \& Godbey, G. (1991). A hierarchical model of leisure constraints. Leisure Sciences, 13(4), 309-320.

Currim, I. S., Weinberg, C. B., \& Wittink, D. R. (1981). Design of subscription programs for a performing arts series. Journal of Consumer Research, 67-75. doi: http:// dx.doi.org/10.1086/208842

Decloe, M. D., Kaczynski, A. T., \& Havitz, M. E. (2009). Social participation, flow and situational involvement in recreational physical activity. Journal of Leisure Research, 41(1), 73-90.

De Rooij, P. (2013). Customer loyalty to performing arts venues (doctoral dissertation). Tilburg University, the Netherlands.

Felton, M. V. (1992). On the assumed inelasticity of demand for the performing arts. Journal of Cultural Economics, 16(1), 1-12.

Field, Andy. (2009). Discovering statistics using SPSS (3rd ed.). Thousand Oaks, CA: Sage Publications.

Funk, D. C., Alexandris, K., \& Ping, Y. (2009). To go or stay home and watch: Exploring the balance between motives and perceived constraints for major events: A case study of the 2008 Beijing Olympic Games. International Journal of Tourism Research, 11(1), 41-53.

Garbarino, E., \& Johnson, M. S. (2001). Effects of consumer goals on attribute weighting, overall satisfaction, and product usage. Psychology \& Marketing, 18(9), 929-949.

Gilbert, D., \& Hudson, S. (2000). Tourism demand constraints: A skiing participation. Annals of Tourism Research, 27(4), 906-925.

Godbey, G., Crawford, D. W., \& Shen, X. S. (2010). Assessing hierarchical leisure constraints theory after two decades. Journal of Leisure Research, 42(1), 111-134.

Havitz, M. E., \& Mannell, R. C. (2005). Enduring involvement, situational involvement, and flow in leisure and nonleisure activities. Journal of Leisure Research, 37(2), 152-177.

Hawkins, B. A., Peng, J., Hsieh, C.-M., \& Eklund, S. J. (1999). Leisure constraints: A replication and extension of construct development. Leisure Sciences, 21(3), 179-192.

Henderson, K. A. (1997). A critique of constraints theory: A response. Journal of Leisure Research, 29(4), 453.

Huang, S. S. (2009). The effects of motivation, past experience, perceived constraint, and attitude on tourist revisit intention. Journal of Travel Research, 48(1), 29-44.

Hudson, S., \& Gilbert, D. (2000). Tourism constraints: The neglected dimension in consumer behaviour research. Journal of Travel \& Tourism Marketing, 8(4), 69-78.

Hung, K., \& Petrick, J. F. (2010). Developing a measurement scale for constraints to cruising. Annals of Tourism Research, 37(1), 206-228.

Kay, P. L., Wong, E., \& Polonsky, M. J. (2009). Marketing cultural attractions: Understanding nonattendance and visitation barriers. Marketing Intelligence \& Planning, 27(6), 833-854.

Kyle, G. T., Absher, J. D., Hammitt, W. E., \& Cavin, J. (2006). An examination of the motivation-involvement relationship. Leisure Sciences, 28(5), 467-485.

Lee, J., \& Beeler, C. (2009). An investigation of predictors of satisfaction and future intention: Links to motivation, involvement, and service quality in a local festival. Event Management, 13(1), 17-29.

Lyu, S. O., \& Oh, C. O. (2015). Bridging the conceptual frameworks of constraints negotiation and serious leisure to understand leisure benefit realization. Leisure Sciences, 37(2), 176-193.

Mahr, D., Lievens, A., \& Blazevic, V. (2014). The value of customer cocreated knowledge during the innovation process. Journal of Product Innovation Management, 31(3), 599-615.

McCarville, R. E., \& Smale, B. J. (1993). Perceived constraints to leisure participation within five activity domains. Journal of Park and Recreation Administration, 11(2), 40-59.

Meijjer, E., Warntjes, A., and Van de Velde, M. (2007). Toneelbezoek, Grote producties in grote zalen: Imago, drempels, motieven en doelgroepsegmenten [Visits to drama, Great productions in big auditoriums: Image, thresholds, motives and targetsegments]. Rotterdam: Elsbeth Meijjer Cultuuronderzoeken.

Mowen, A. J., Payne, L. L., \& Scott, D. (2005). Change and stability in park visitation constraints revisited. Leisure Sciences, 27(2), 191-204.

Nadirova, A., \& Jackson, E. L. (2000). Alternative criterion variables against which to assess the impacts of constraints to leisure. Journal of Leisure Research, 32(4), 396.

Nicholson, R. E., \& Pearce, D. G. (2001). Why do people attend events? A comparative analysis of visitor motivations at four South Island events. Journal of Travel Research, 39(4), 449-460.

Nyaupane, G. P., Morais, D. B., \& Graefe, A. R. (2004). Nature tourism constraints: A cross-activity comparison. Annals of Tourism Research, 31(3), 540-555.

Oliver, R. L. (1999). Whence consumer loyalty? Journal of Marketing, 63(4), 33-34. 
Özdemır, G., \& Çulha, O. (2009). Satisfaction and loyalty of festival visitors. Anatolia: An International Journal of Tourism \& Hospitality Research, 20(2), 359-373.

Palen, L.-A., Patrick, M. E., Gleeson, S. L., Caldwell, L. L., Smith, E. A., Wegner, L., \& Flisher, A. J. (2010). Leisure constraints for adolescents in Cape Town, South Africa: A qualitative study. Leisure Sciences, 32(5), 434-452.

Pegg, S., \& Patterson, I. (2010). Rethinking music festivals as a staged event: Gaining insights from understanding visitor motivations and the experiences they seek. Journal of Convention \& Event Tourism, 11(2), 85-89.

Pritchard, M. P., Funk, D. C., \& Alexandris, K. (2009). Barriers to repeat patronage: The impact of spectator constraints. European Journal of Marketing, 43(1/2), 169-187.

Quintal, V. A., \& Polczynski, A. (2010). Factors influencing tourists' revisit intentions. Asia Pacific Journal of Marketing and Logistics, 22(4), 554-578.

Reddy, S., Swaminathan, V., and Motley, C. (1998). Exploring the determinants of Broadway show success. of Marketing Research, 35(3), 370-383.

Saleh, F., \& Ryan, C. (1993). Jazz and knitwear: Factors that attract tourists to festivals. Tourism Management, 14(4), 289-297.

Santos-Lewis, R., \& Moital, M. (2013). Constraints to attend events across specialization levels. International Journal of Event and Festival Management, 4(2), 107-124.

Scheff Bernstein, J. (2006). Arts marketing insights. San Francisco: Pfeiffer Wiley.

Schimmelpfennig, J. (1997). Demand for ballet: A nonparametric analysis of the 1995 royal ballet summer season. Journal of Cultural Economics, 21(2), 119-127.

Schofield, P., \& Thompson, K. (2007). Visitor motivation, satisfaction and behavioural intention: The 2005 Naadam Festival, Ulaanbaatar. International Journal of Tourism Research, 9(5), 329-344.
Shen, S. (2014). Intention to revisit traditional folk events: A case study of Qinhuai Lantern Festival, China. International Journal of Tourism Research, 6(5), 513-520.

Thrane, C. (2002a). Jazz festival visitors and their expenditures: Linking spending patterns to musical interest. Journal of Travel Research, 40(3), 281-286.

Thrane, C. (2002b). Music quality, satisfaction, and behavioral intentions within a jazz festival context. Event Management, 7(3), 143-150.

Uncles, M. D., Dowling, G. R., \& Hammond, K. (2003). Customer loyalty and customer loyalty programs. Journal of Consumer Marketing, 20(4), 294-316.

Van den Broek, M. (2008). Klantloyaliteit in theaters, meer dan het lijkt [Customer loyalty in theatres, more than it seems] (master thesis). University of Tilburg, the Netherlands.

Verhoeff, R., \& Ganzeboom, H. (1991). Cultuur en publiek: Multidisciplinaire opstellen over de publieke belangstelling voor kunst en cultuur in Nederland. [Culture and audience: Multidisciplinary papers about the public interest in arts and culture in the Netherlands]. Amsterdam: SISWO.

Wan, Y. K. P., \& Chan, S. H. J. (2013). Factors that affect the levels of tourists' satisfaction and loyalty towards food festivals: A case study of Macau. International Journal of Tourism Research, 15(3), 226-240.

Zaichkowsky, J. L. (1985). Measuring the involvement construct. Journal of Consumer Research, 12(3), 341.

Zanon, D., Doucouliagos, C., Hall, J., \& Lockstone-Binney, L. (2013). Constraints to park visitation: A meta-analysis of North American studies. Leisure Sciences, 35(5), 475-493.

Zomerdijk, L. G., \& Voss, C. A. (2010). Service design for experience-centric services. Journal of Service Research, 13(1), 67-82. 